Saudi Journal of Medical and Pharmaceutical Sciences

Abbreviated Key Title: Saudi J Med Pharm Sci

ISSN 2413-4929 (Print) |ISSN 2413-4910 (Online)

Scholars Middle East Publishers, Dubai, United Arab Emirates

Journal homepage: https://saudijournals.com/sjmps

Original Research Article

\title{
Current Scenario of Antibiotic Resistant on Indian Community: A Case Study
}

\author{
Subhash Chand ${ }^{1 *}$, Mohd. Arshad ${ }^{1}$, Ritu Yadav ${ }^{1}$, Arjun Singh ${ }^{2}$ \\ ${ }^{1}$ College of Pharmacy, Roorkee, Uttarkhand- India \\ ${ }^{2}$ Smt. Tarawati Institute of Bio-Medical and Allied Sciences, Roorkee, Uttarkhand- India
}

\begin{abstract}
DOI: $10.36348 /$ sjmps.2020.v06i02.002
| Received: 27.01.2020 | Accepted: 03.02.2020 | Published: 08.02.2020

*Corresponding author: Subhash Chand
\end{abstract}

\section{Abstract}

There is at present no comprehensive consensus on methodology and data collection for ABR surveillance. Schedule surveillance in most countries is often based on samples taken from patients with severe infections- particularly infections associated with health care, and those in which first-line treatment has failed. Community-acquired infections are almost positively under represented among samples, leading to gaps in coverage of important patient groups. Increasing incomes and a growing population are driving an increased demand for animal products in India, as is the case in other low and middle-income countries. Food animals are measured as key reservoirs of antibiotic-resistant bacteria with the use of antibiotics in the food production industry having contributed to the actual global challenge of ABR. In the modern era the utilization of dietary chicken is gradually increasing in India because more chicken is being consumed by the non-vegetarian populations. The recommended levels of AMAs in feed were 5- $10 \mathrm{~g} / \mathrm{kg}$ in 1950 's and have since increased 10-20 times. The present case study is conducted in Dehradun region of Uttrakhand state of India to evaluate and assess the antibiotics mistreatment in the population. Center for Science and Environment (CSE) report indicating antibiotic residues in poultry is considered as ground motive to analyze the locality and record their antibiotic uses outcomes. The present surveillance based on the questionnaire survey; participants were interviewed with open and closed-ended questions. A total 100 individuals were involved in the study. $60 \%$ of the patients consult a doctor before starting antibiotics whereas $40 \%$ of the patients accepted that they do not consult a doctor before starting antibiotics. The recent history to suffer from a viral disease was positive in $60 \%$. Consequently, it is accomplished that non-vegetarians are at great risk of developing antibiotic resistant due to irrational use of antibiotics among poultry along with adverse drug reaction of ADRs. The development \& progression of Antibiotic resistant in Indian patients is influenced by their socioeconomic class.

Keywords: Antibiotic Resistant Poultry, AMAs, ADRs, antibiotic use, antibiotic resistance, irrational use of antibiotics .

Copyright @ 2020: This is an open-access article distributed under the terms of the Creative Commons Attribution license which permits unrestricted use, distribution, and reproduction in any medium for non-commercial use (NonCommercial, or CC-BY-NC) provided the original author and source are credited.

\section{INTRODUCTION}

The dietary chicken consumption is increasingly in India because more chicken is being consumed by the non-vegetarian populations over the years. It is therefore necessary that with time, the quality of poultry is regularly and stringently monitored and maintained to ensure that consumers get healthy meat of chicken. In the recent past, the news has repeatedly appeared in media about chicken being administrated higher doses of newer and higher antimicrobials agents (AMAs) for prevention of feared diseases. The recommended levels of AMAs in feed were $5-10 \mathrm{~g} / \mathrm{kg}$ in 1950 's and have since increased 10 20 times1, which is alarming and therefore worth concern [2]. In Europe, approximately $50 \%$ of all AMAs used annually are given to animals. The AMAs used in therapy, for prevention of bacterial infections, promoting growth, increasing feed efficacy and decreasing waste production are known as feed savers, AM growth promoters or antimicrobial performance enhancers (APE)[1]. Approximately 30\% of all AMAs used in animals are used as APE.2The APE is mainly active against gram positive bacteria3 with the exception of carbadox and olaquindox, which are mainly active against gram negative. The New Delhi based NGO Center for Science and Environment (CSE) during their recent study found residues of AMAs in $40 \%$ of the chicken samplestested. The AMA inventive capability of humans is finite and resistance developed by micro-organisms is steadily rising and infinite. Regrettably, no new class of AMA has hit the market since late 1980s. Repeated and prolonged exposure to 
AMAs leads, by natural selection; to the emergence of resistant strains of bacteria. Classes of the AM that are used in poultry include cephalosporin, penicillin and macrolides. Cephalexin, a cephalosporin, amoxicillin from the penicillin group and azithromycin, which is a macrolide, is used in broiler and is critical for human use as per the WHO. Many studies have reported gross misuse of AMAs in chickens. After survey of the recent reports, we felt that all was not well with use of AMAs in Indian poultry farms. Hence this survey was planned of find the pervasiveness of AM use and pattern of prevalence in Dehradun area of Uttarakhand, India [47].

Global use and irrational use of antibiotics/ antibacterial agents' in humans, animals, agriculture and food

\begin{tabular}{|l|l|l|l|l|}
\hline S.No. & $\begin{array}{l}\text { Host/ Common } \\
\text { site of irrational } \\
\text { use of drug }\end{array}$ & \multicolumn{1}{|c|}{ Reason } & $\begin{array}{c}\text { Irrationally used } \\
\text { drugs }\end{array}$ & \multicolumn{1}{|c|}{ Impact/ Outcome on Community } \\
\hline 1 & $\begin{array}{l}\text { Animals Feed } \\
\text { To Prevent } \\
\text { Opportunistic } \\
\text { infections and enhance } \\
\text { production }\end{array}$ & $\begin{array}{l}\text { Treatment of various } \\
\text { diseases and infections }\end{array}$ & $\begin{array}{l}\text { Reduced immune stimulation due to } \\
\text { stress caused by overcrowding of the } \\
\text { animals modification of rumen } \\
\text { microbial metabolism }\end{array}$ \\
\hline 2 & Humans & Food Preservative. & $\begin{array}{l}\text { chlortetracycline, } \\
\text { oxytetracycline, } \\
\text { chloramphenicol, } \\
\text { penicillic acid, } \\
\text { penicillin and } \\
\text { streptomycin }\end{array}$ & $\begin{array}{l}\text { Antibiotic Resistant among the } \\
\text { population leading to complications and } \\
\text { treatment failures }\end{array}$ \\
\hline 3 & Food industry & $\begin{array}{l}\text { Predisposing consumers to sub- } \\
\text { cause selection of antibiotic resistant } \\
\text { bacteria pathogens in humans, animals } \\
\text { and environment. }\end{array}$ \\
\hline 4 & Horticulture & $\begin{array}{l}\text { Treatment of plants/ } \\
\text { crop diseases }\end{array}$ & $\begin{array}{l}\text { Oxytetracycline } \\
\text { and streptomycin }\end{array}$ & $\begin{array}{l}\text { Their massive use promotes the selection } \\
\text { and emergence of resistant bacterial } \\
\text { strains in both humans and animals }\end{array}$ \\
\hline 5 & Environment & Various & Antibiotic Pollution \\
\hline
\end{tabular}

\section{Antibiotic resistance: Mechanism [8-10]}

In the environment the bacterial organisms are bare to sub-therapeutic concentrations of these antibiotics where some are killed and others develop resistant mechanisms to avoid the drugs. The antibiotic resistant bacteria organisms are selected from the several populations of bacteria in the environment mainly by horizontal gene transfer mechanisms and then spread to both humans and animals globally causing severe bacterial diseases that contribute to high morbidity and mortality.

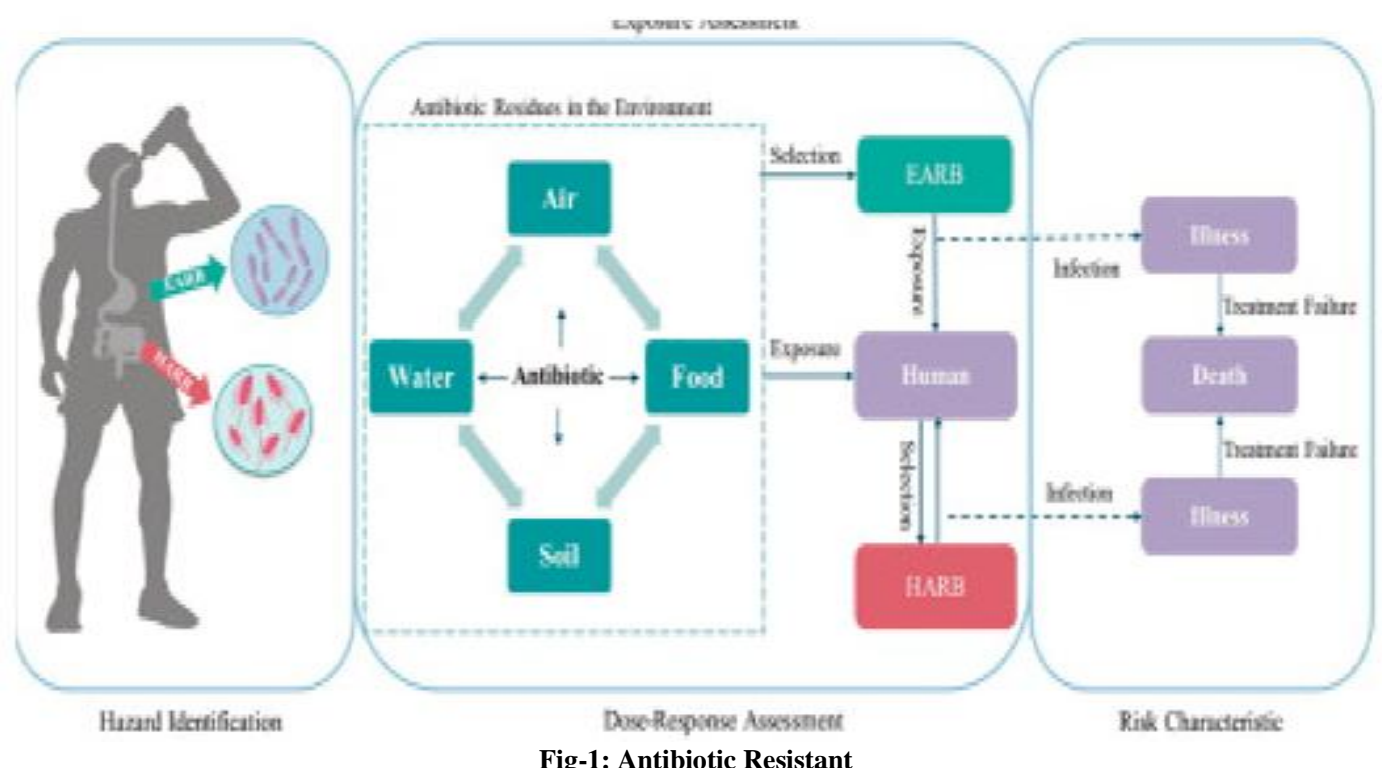

Fig-1: Antibiotic Resistant 


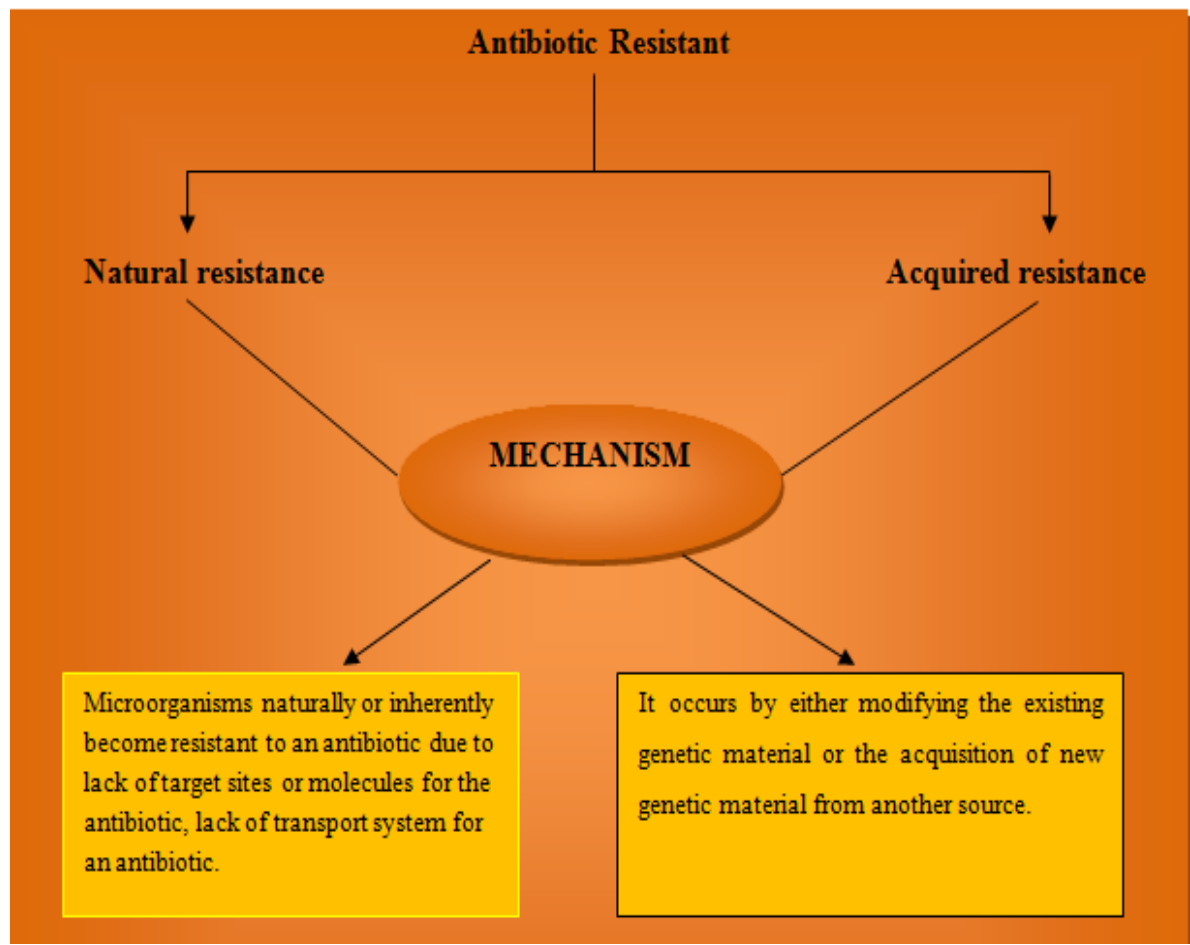

\section{Methodology \\ Study design}

The study is based on the questionnaire survey, conducted in rural \& urban area of Roorkee. The study participants were interviewed with open and closed-ended questions. The data thus collected was processed \& analyzed. The questionnaire was developed in English \& translated into Hindi (local language). The responses from the individuals were recorded. In questionnaire, social economic \& demographic information (age, gender, area of living, religion, occupation) of the responding consumer were also collected. Data was analyzed using Microsoft excel. Social and demographic profiles of the patients were tabulated using simple descriptive statistics. The study was conducted in April 2015 with 100 patients from all fields to test the instrument, determine application time, and clarify possible questions from the particulars.

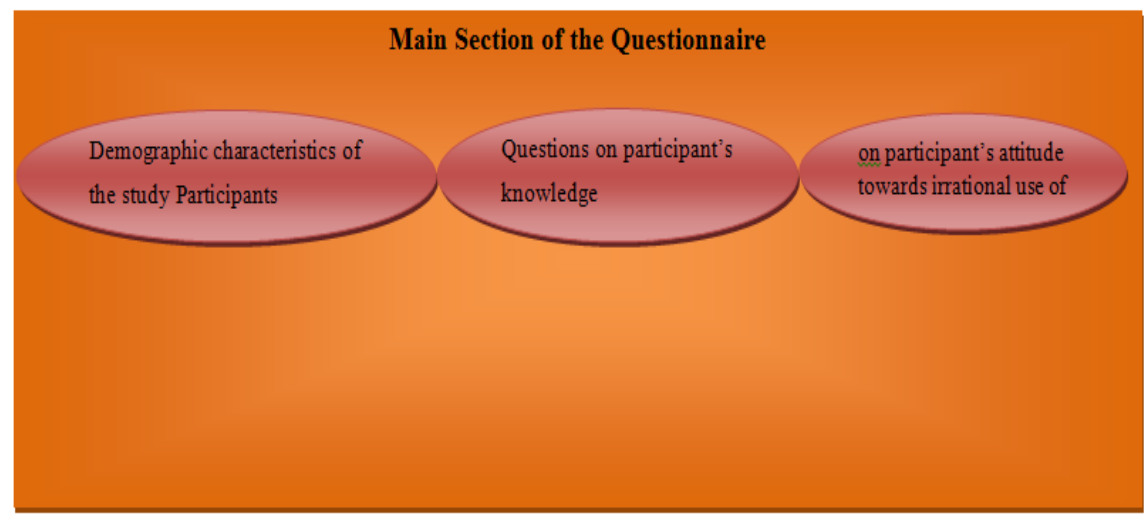

\section{Data Analysis}

Social and demographic summary of the patients was tabulated using simple descriptive statistics in the Microsoft excel.

\section{RESULT AND DiSCUSSION Demography}

A total 100 individuals were involved in the study. Most of them were between 21-30 age groups (42\%). The result was tabulated in fig $2 \& 3$. Both vegetarians and non vegetarians of the major religions of the locality (Hindu (46\%), Muslim (25\%), Sikh $(11 \%)$ \& Christian (18\%)) were included. Majority of the population was literate (undergraduates $(52 \%)$ ) and 
of working class. The result was tabulated in fig $4 \& 5$. The survey showed that $60 \%$ of the patients consult a doctor before starting antibiotics whereas $40 \%$ of the patients accepted that they do not consult a doctor before starting antibiotics. The adverse effect of the ADRs observed that Nausea (30\%), Vomiting (30\%), Diarrhea $(20 \%) \&$ Rash $(20 \%)$ are the most common ADRs among them.

\section{Summary \& CONCLUSION}

Antibiotics/antibacterial agents play significant role towards combat of the ecological factors in the environment that could potentially affect almost all microbial communities. The massive misuse and abuse of antibiotics leads to their buildup in the environment especially the quinolones that are slowly biodegradable. In the environment, they cause deleterious effects to the bacterial population such as phylogenetic structure alteration, resistance expansion and ecological function disturbance in the micro-ecosystem. The ecological functional turbulence by the antibiotics in the environment includes nitrogen transformation, methanogenesis and sulfate reduction. The increased antibiotic concentrations in natural ecosystems have a significant consequence in human therapy in hospitals and livestock production and in agriculture due to the increased selection of the antibiotic resistant pathogenic bacteria organisms that can spread globally. These changes also contribute to structural alteration of the natural microbial populations and also alteration of the physiology of microorganisms. The selection of the antibiotic-resistant mutants favors the acquisition of antibiotic resistance determinants by gene-transfer of elements that can spread among the environmental microbiota. The antibiotic pollution can enrich the bacterial population with intrinsically resistant microorganisms and reduce the population of susceptible microbiota like Cyanobacteria, which are responsible for more than a third of total free $\mathrm{O} 2$ production and $\mathrm{CO} 2$ in the environment. The increased elimination of the Cyanobacteria population due to antibiotic/antibacterial agents pollution poses a great threat to the natural environment and the survival of all Microbiota, animals and humans and hence the maintenance of the global activity of the microbiosphere and macrobiosphere. Even though a reduction in the prevalence of resistance has been reported after discontinuation of a given antibiotic, the total restoration of bacterial population to its previous antibiotic susceptible situation is not easily achievable. Many promising bacterial diseases due to increased resistant pathogenic organisms from the environment are likely to increase in the future that would lead to a significant mortality of both humans and animals if the trend of antibiotics/antibacterial drugs use globally is not changed, the situation may return to the preantibiotic golden age. Non vegetarians are at great risk of developing antibiotic resistance due to irrational use of antibiotics among poultry. The development \& progression of Antibiotic resistant in Indian patients is influenced by their socioeconomic class \& age group, it's due to family history \& environmental factors. Nonprescription use of antibiotics is another most prevalent form. Poor knowledge about antibiotic use plays a noteworthy role in irrational antibiotic use. There is a strong need to review the use of antibiotics in poultry farms and drug outlets.

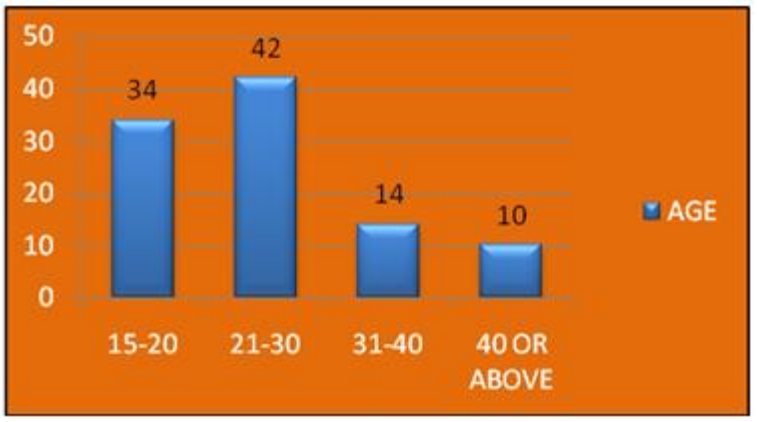

Fig-2: Relationship between age and patient

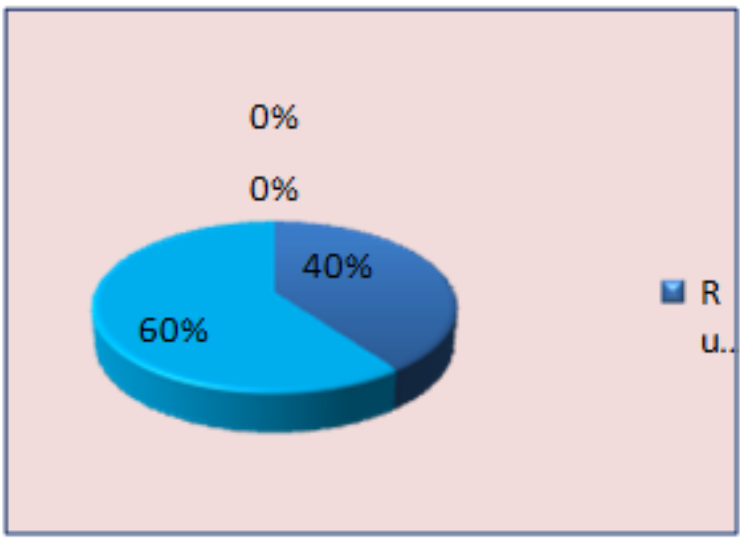

Fig-3: Relatiomship between areas of living \& patient

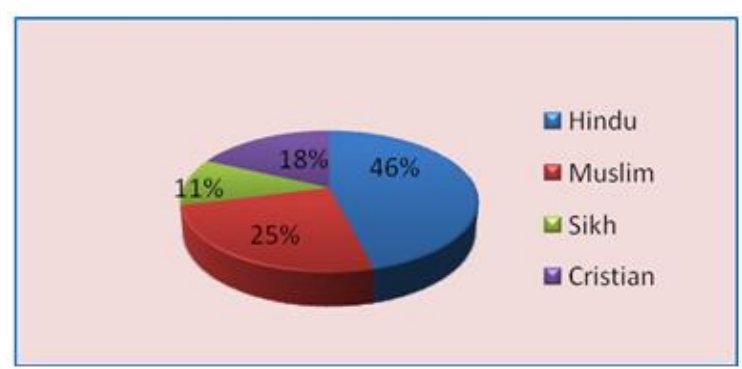

Fig-4: Relationship between religions \& patients

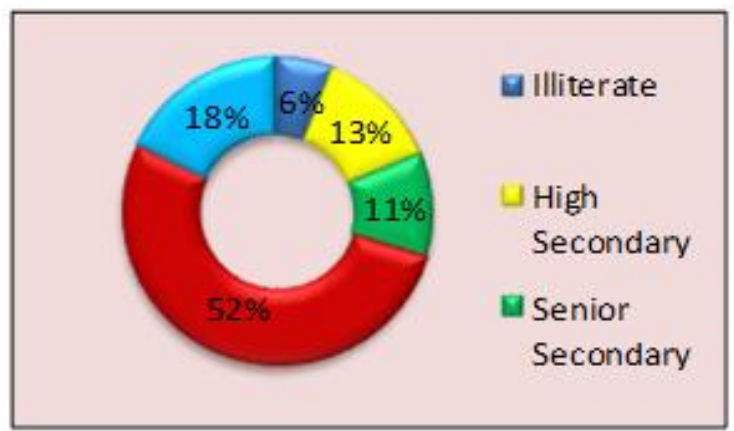

Fig-5: Relationship between education \& patients 


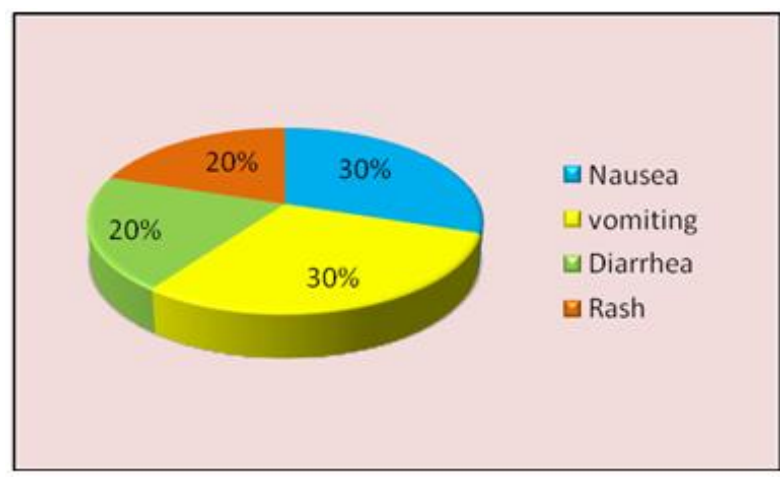

Fig-6: Common ADR of antibiotics

\section{REFERENCES}

1. American College of Obstetricians and Gynecologists. (2001). Antibiotic prophylaxis for gynecologic procedures. ACOG practice bulletin, 23.

2. Network, S. I. G. (2008). Antibiotic prophylaxis in surgery. A national clinical guideline. Elliot House: Edinburgh.

3. Krukowski, Z. H., \& Bruce, J. (2008). Commentary: controversies in NICE guidance on surgical site infection. Bmj, 337, a2120.

4. Ghafur, A. (2012). Can India be the wing commander in the global fight against antimicrobial resistance? J Assoc Physicians India, 60, 42-3.

5. Hammerum, A. M., Toleman, M. A., Hansen, F., Kristensen, B., Lester, C. H., Walsh, T. R., \& Fuursted, K. (2010). Global spread of New Delhi metallo- $\beta$-lactamase 1 . The Lancet infectious diseases, 10(12), 829-830.

6. Zeh, J. A., Bonilla, M. M., Adrian, A. J., Mesfin, S., \& Zeh, D. W. (2012). From father to son: transgenerational effect of tetracycline on sperm viability. Scientific reports, 2(1), 1-5.

7. Niël-Weise, B. S., Van den Broek, P. J., Da Silva, E. M., \& Silva, L. A. (2012). Urinary catheter policies for long-term bladder drainage. Cochrane Database of Systematic Reviews, (8).

8. Niël-Weise, B. S., \& van den Broek, P. J. (2005). Antibiotic policies for short-term catheter bladder drainage in adults. Cochrane Database of Systematic Reviews, (3).

9. http://www.cdc.gov/getsmart/campaignmaterials/w eek/ index.html accessed on 19.06.13 (2013)

10. Van den Bogaard, A. E., \& Stobberingh, E. E. (2000). Epidemiology of resistance to antibiotics: links between animals and humans. International journal of antimicrobial agents, 14(4), 327-335. 